\title{
Pemberdayaan IPM Melalui Perpustakaan Mini Sebagai Upaya Meningkatkan Produktivitas Baca-Tulis di Kapas Madya Baru Surabaya
}

\author{
M. Ridlwan', Asy'ari' \\ ${ }^{1,2}$ Fakultas Keguruan dan Ilmu Pendidikan, Universitas Muhammadiyah Surabaya \\ Email: asyarifurqan@gmail.com²
}

\begin{abstract}
ABSTRAK
Perpustakaan merupakan hal yang paling penting dalam mengasah pengetahuan remaja. Maka sebagai strateginya dalam rangka membentuk produktivitas mabaca dan nenulis remaja. Karena remaja dengan kelabilannya sangat sensitif dengan keaadaan lingkungan sehingga memicu pada kenakalan remaja. Oleh karena itu, pengabdian ini dilakuakan selama alokasi waktu satu bulan melalui pengadaan perpustaan mini multi sumber yang dibentuk kegiatannya melalui bimbingan dengan bentuk pelatihan-pelatihan atau workshop yang memang remaja sagat strategis dalam pembentukan tumbuhkembangnya produktivitas baca-tulis. Hasil kegiatan yang diperoleh menunjukkan bahwa pembentukan budaya baca-baca tulis melalui perpustakaan multi-sumber dilakukan dengan bimbingan secara inten. Workshop atau pelatihan-pelatihan kemampuan membaca dan menulis dapat mempermudah remaja IPM membutikan kreativitas dan inovasinya. Sehingga denagan kegitan seperti itu sedikit banyak dapat meminimalisir kenakalan remaja. Maka dari itu, kebutuhan untuk mengadakan perpustakaan mini di sebuah masjid dengan kegiatan pemberdayaan baca tulis remaja harus dilakukan secara berkelanjutan.
\end{abstract}

Kata Kunci: IPM,Perpustakaan Mini, Produktivitas Baca

\section{PENDAHULUAN}

Di era kontemporer saat ini, masalah terkait dengan kenakalan remaja semakin kompleks, berbagai probelma muncul karena kenakalan remaja. Padahal remaja merupakan aset masa depan bangsa. Ketika suatu bangsa remaja atau pemudanya rusak tidak bermoral, maka tunggulah saat kehancurannya. Soekarno pernah meyatakan "berilah aku 10 pemuda maka akan kugoncangkan dunia" (Aditya, 2007). Sehingga bisa dikatakan apa yang disampaikan Bung Karno itu para pemuda atau remaja adalah tolak ukur keberhasilan suatu bangsa dan Negara.

Saat ini dari berbagai media massa bisa dilihat bahwa para pemuda atau remaja membuat gelisah suatu bangsa. Para remaja sekarang ini sebagian besar lebih senang berbuat maslah publil daripada memberi kontribusi terhadapa kelangsungan dan kemajuan suatu bangsa dan Negara. Hal ini sangat ironis ketiak melihat kejanggalan-kejanggalan yang dilakukan oleh anak-anak muda zaman sekarang ini. Karena kenakalan remaja tidak bisa dipungkiri pasti dipengaruhi oleh lingkungan sekitar, baik lingkungan kelurga, Masyarakat dan lingkungan pendidikan. Karena menurut John Lock dalam teorinya, bahwasanya anak yang dilahirkan bagaikan "Tabularasa" kosong tidak terkontaminasi apapun, sehingga lingkunganlah yang akan mempengaruhi kepribadian baik dan tidakny anak (Nindya \& Margaretha, 2012).

Salah satu faktor penyebab timbulnya kenakalan remaja khusunya yang berada disekitar kapas baru adalah tidak berfungsinya orangtua sebagai figur tauladan bagi anak. Selain itu suasana keluarga yang menimbulkan rasa tidak aman dan tidak 
menyenangkan serta hubungan keluarga yang kurang baik dapat menimbulkan bahaya psikologis bagi setiap usia terutama pada masa remaja. Dalam kehidupan sosial, remaja banyak sekali dipengaruhi oleh teman sebaya. Biasanya para remaja menghabiskan waktu dua kali lebih banyak dengan teman sebayanya daripada, dengan orang tuanya. Oleh karena itu remaja lebih banyak berada di luar rumah bersama dengan teman-teman sebaya. Perilaku menyimpang dapat dianggap sebagai sumber masalah karena dapat membahayakan tegaknya sistem sosial (Murtiyani, 2011). Pembinaan remaja atau pemuda sangat penting untuk dimaksimalkan, sehingga paling tidak dengan berbagai agenda terkait penyuluhan atau worksop dan lain sebagainya, akan meminimalisir dari kenakalan yang terjadi pada remaja tersebut.

Wilayah kapas baru secara observatif remajanya relatif banyak, dengan karakter yang bermacam-macam. Maka dari itu tidak semua orang tua memiliki kesadaran untuk menyekolahkan anaknya setinggitingginya. Faktor yang menjadi kedala tidak menyekolahkan anaknya kejenjang lebih tinggi adalah ekonomi. Orientasi dari para orang tua hanya fokus bagaimana anaknya pasca sekolah mendapatkan pekerjaan yang baik. Padahal seharusnya anak-anak tidak hanya diorientasikan untuk bekerja yang hanya mengedepankan skill bersifat psikomotorik, tetapi tidak berorientasi pada bagaimana anak secara moralitas bagus dan relegius. Sehingga para remaja yang seperti ini hanya fokus pada dunia kerja, namun sebagian banyak anak remaja kapas baru nganggur dengan tidak memiliki pekerjaan yang tetap.

Permasalahan remaja tidak hanya yang bertanggung jawab penuh adalah keluarga, namun lembaga formal seperti seperti sekolah dan lembaga-lembaga lain harus ikut andil dalam ranka menyelesaikan permasalahan pada remaja. Dalam pengelolaan ikatan pelajar melalu perpustakaan mini dengan berbagai sumber ditambah dengan pelatihan-pelatihan atau workshop yang bersifat mendidik, tentunya akan berdampak positif pada kehidupan remaja dilingkungan kapas baru. Karena hal ini merupakan treatment yang relevan untuk mengkondisikan para remaja memilki karakter yang baik dan menjadi pribadi yang shaleh dengan memilki wawasan yang luas. Namun pemberdayaan Ikatan pelajar ditingkat ranting masih belum begitu banyak, karena pemudanya lebih senang pada yang bersifat yuforia daripada mendidikasikan diri ke masjid.

Penelitian Shanty, dkk (2014) menyimpulkan bahwa kenakalan remaja terjadi karena kurang tersedianya waktu orang tua untuk mendidik anak karena kesibukannya bekerja dan menyelesaikan tugas rumah tangga, tidak adanya pengawasan dari orang tua atau saudara, pengaruh lingkungan sekitar tempat tinggal anak, pengaruh teman sepermainan serta karena faktor kesenangan, kepuasan, penasaran dan rasa kebanggaan dari para remaja sendiri. Sementara hasil peelitian yang lain Sriyanto, dkk (2014) menunjukkan bahwa pembentukan sikap dan perilaku asertif sangat penting pada diri remaja sebab masa ini merupakan masa yang menentukan bagi perkembangan kepribadian selanjutnya. Perilaku asertif memiliki pengaruh yang signifikan negatif terhadap kecenderungan kenakalan remaja. Perilaku dibentuk melalui konteks sosial yang dapat dipelajari baik sebagai hasil reinforcement maupun motivasi intrinsik itu sendiri.

Oleh karena itu, dari dua hasil penelitian menunjukkan bahwa kenakalan remaja sangat dipengeruhi oleh lingkungan sekitar, baik keluarga, masyarakat dan lingkungan pendidikan. Sejalan dengan itu, remaja memang sangat sensitif terintervensi dari berbagai hal. Maka dapat dipahami bahwa harus ada strategi yang harus digunakan dalam rangka meminimalisir dari kenakalan remaja yang terjadi. Preode remaja sangat 
dekat dengan identitas diri yang diakui oleh kelompok yang disinggahinya, karena identitas baru dapat memicu harga diri seorang remaja. Maka tentunya dalam rangka menfasilitasi dari remaja setempat membutuhkan wadah strategis yang dapat memicu peningkatan produktivitas bacatulis yang berada dikawasan kapas baru masjid Al-furqan III/13 Surabaya.

Dalam layanan pemberdayaan dibentuk IPM sebagai identitas baru yang sebelumnya atas nama Remaja masjid (REMAS) masjid al-furqan. Namun sesuai dengan berjalannya waktu yang sebelimnya remas menjadi Ikatan Pelajar Muhammadiyah (IPM) Bertepatan pada Bulan Juli 2016. Dalam pembinaan dibuatlah kegiatan secara rutin sebagai pemicu pembiasaan baik kepada remaja dan difasilitasi pula perpustakaan mini multi-sumber sebagai penarik perhatian mereka dalam membaca dn menulis. Karena dengan banyak membaca tenunya turunannya kepada menulis. Sehingga hal seperti itu harus benar-benar dilakukan secara masif dan difasiitasi dengan baik.

Maka pemberdayaan remaja yang dilakukan melalui pembentukan IPM dengan kegiatan yang masif dan difalitasi perpustakaan multi-sumber. Kemudian pembimngan kepada mereka secara rutin baik. Secara formal mereka dibentuk acara (a) Muhadhoroh yaitu berfungi sebagai bentuk pembiasaan diri kader IPM tampil sebagai pembicara didepan umum, (b) Diskusi rutin yaitu berfungsi memperbanyak wawasan keilmuan kader IPM yang menjadi bekal dalam kehidupan sehariri, (c) Agenda nulis rutin yaitu berfingsi mengasah keterampilan menulis secara baik, dengan menulis tulisan arab dan latin, sehingga menjadi satu padu, (d) Pengembangan yaitu berfungsi untuk menumbuhkembangkan keder IPM dari berbagai hal yang nantinya menghasilkan produk inovasi.

Tujuan kegiatan ini adalah dalam rangka menjadikan perputakaan mini multi-sumber ini sebagai media pembelajaran dalam mengasah produktivitas baca tulis yang berwawasan tinggi, sehingga dapat meningkatkan potensi diri kader IPM secara maksiamal. Menjadikan kader IPM selalu progresif dan militan serta memiliki loyalitas tinggi dari sebauah pergerakan. Sehingga mampu menjadi pribadi yang sanggup menyelesaikan berbagai persoalan kehidupan.

Target yang ingin dicapai dalam kegiatan ini adalah: (a) Menumbuh kembangkan kader IPM dalam keterampilan memebaca dan menulis melalui perpustakaan multi-sumber, (b) Peran aktif kader IPM dalam berbagai kegitan yang dikelola oleh pimpnan ranting muhammadiya kapas baru di Masjid Al-Furqan III/13 Surabaya, (c) terciptanya perubahan pola pikir kader IPM menjadi lebih kreatif dan inovatif, (d) Mengoptimalisasikan sinergisitas antara

\section{METODE PELAKSANAAN}

Rendahnya minat baca tulis menjadi perhatin serius bagi kita semu, khususnya di daerah kapas baru merupakan masalah besar bagi berlangsungnya sebuah peradaban. Sehingga dengan minimnya minat baca tulis yeng terjadi di kapas baru menjadi masalah bersama yang harus direncanakan dalam penyelesaiannya. Kemudian dengan merencanakan program yang dibuat oleh Pimpinan Ranting Kapas baru yang sekretareatnya di Masjid Al-Furqan Jalan Kapas Madya III/13 Surabaya dengan mengadakan perpustakaan mini muli-sumber, dalam rangka membangkitkan spirit produktiviatas baca tulis IPM Ranting Kapas Baru. Selain itu dapat ditunjang melalui mediator pembimbing dalam mengarakkan pada target yang diinginkan. Pembuktian pengadaan perpustakan mini merupakan media strategis untuk diimplementasikan yang berkelanjutan, dengan Jumlah sasarn anggota kader IPM sebanyak 25 orang.

Metode kegiatan yang digunakan dalam pengabdian ini yaitu melalui pendampingan dan pelatihan sebagai upaya menciptakan produktivitas baca tulis dilakukan dengan cara: 
a) Mohadhrah, kegiatan ini dilakukan setiap satu minggu sekali dengan memberikan kesempatan kepada kader untuk membaca dan menulis melalui sumber di perpustakaan yang telah disiakan di Masjid Al-Furqan.

b) Worshop (pelatihan), pada kegiatan ini diakukan sectengah bulan sekali dan mempreoritaskan transfer pengetahuan langsung kepada kader IPM yang dikemas secara sistematis dalam mengkonstruk pemahaman kader dan meberi kebebasan untuk berdiskusi terhadap materi yang disampaikan dalam rangka mereview agar menimbulkan pemahaman yang sempurna.

c) FGD (Focused Group Discussion), hal ini merupakan suatu teknik diskusi kelompok sebagai bentuk gambaran terkait dengan problema kehidupan. Dari buku yang ada di perpustakaan mini, kader diberikan kebebasan untuk membaca dan menuliskan sebagai diskusi, dengan tema yang telah ditetapkan sebelumnya.

d) Reflesi, sebagai upaya pencapaian untuk mengetahui untuk memahami secara kritis yang telah dilakukan sebelumnya. Kemudian penerapan ini dengan menggunakan perpustakaan multi-sumber benarbenar apakah ada pengaruh terhadap produktivitas baca tulis keder IPM Kapas Baru Kota Surabaya.

Mikanisme atau tahapan pelaksanaan melalui perpustakaan mini multi-sumber dengan mewaujudkan kreatifitas dan berwawasan tinggi adalah sebagai berikut:

a) Persiapan Pengabdian; tahapan disini tentunya tim pengabdian mebentuk relasi atau mitra dalam rangka melaksankan kegiatan yang akan diimplementasikan di daerah sasar dengan menjadikan tempat prngabdian.

b) Sosialisasi Pengabdian, pada tahap ini tim pengabdian mempresentasikan langkah-langkah yang akan menjadi kegiatan rutin di Ranting
Kapas Baru berkaitan dengan mikanisme pelaksanaan kegiatan pengabdian melalui perpustakaan mini upaya meningkatkan produtivitas baca tulis kader.

c) Worksop awal, kegiatan ini sebagai media untuk memotivasi kader, yang kemudian kader diberikan pemahaman terkait dengan pentingnya membaca dan menulis sebagai kaya yang harus menjadi perhatian. Kader IPM yang di Ranting Kapas Baru berjumalah 25 anak, sehingga dengan pelatian intensif akan memicu produktivitas kader dalam rangkan membaca dan menulis di perpustakaan mini dengan multi-sumber yang telah disiapakan.

d) Workshop keberlanjutan, pada hal ini tim pengabdian menindaklanjuti pelatihan yang sebumnya telah dilakukaan, fokus pada target pada pembentukan produktifitas baca tulis melalui perpustakaan mini terhadap kader IPM Ranting Kapas Baru Kota Surabaya. Para tahapan ini kader memang didesain untuk diarahkan cara mudah membaca dan menulis, sehingga setelah pelatihan diberikan kepada mereka langsung dibuktikan secara kontekstual seberapa pengaruh pelatihan yang telah diterapkan.

e) Pendampingan pengabdian, yang menjadi ukuran tahapan ini adalah tim pengabdian menentukan pendampingan selama kegitan berlangsung, memperhatikan kesalahan-kesalahan kader dalam mengerjakan tugas yang telah diberikan, kemudian diarahkan kepada yang lebih baik. Karena degan pendampingan seperti ini merupakan cara strategis untuk mengetahui secara langsung apa yang terjadi dilapangan.

f) Evaluasi pengabdian, pada tahapan terakhir ini, tim pengabdian masyarakat dan juga tidak ketinggalan pimpinan ranting kapas baru dan takmir masjid Al-Furqan mengevaluasi kegitan yang telah 
dilakukan sebarapa besar kemajuan kader dalam baca tulis kader IPM melalui perpustakaan mini multisumber yang nantinya menjadi kader masa depan bangsa dan Negara.

\section{HASIL DAN PEMBAHASAN HASIL}

Pada kegiatan yang ini dilakukan sebagai upaya menumbuhkan budaya baca tulis kader IPM melalui perpustakaan mini multi sumber, maka sesusuai dengan rencana yang konsep sebelumnya walaupun ada kendala, tapi tidak berdampak pada berlangsungnya pengabdian ini sampai selesai, sehingga kegiatan ini di mualai dari:

\section{a. Persiapan (Preparation)}

Pada kegiatan ini secara khusus diperlukan waktu persiapan yang harus difikir secara kolaboratif bersama tim dan melakukan SWOT dalam rangka mensukseskan rangkaian pengabdian dalam rogram yang ditawarkan kepada masyrakat. Karena SWOT sangat efektif untuk menjadikan program tepat sasaran dan sesuai dengan yang diharapkan.

Persiapan yang yang dilakukan melalui beberapa tahapan diantaranya yaitu: 1) Sosialisasi dan koordinasi, tahapan ini merupakan pemberdayaan mitra sasaran yang akan dilakukakan pengabdian, terutama yang berkaitan dengan jadwal sangat urgent untuk disipkan. Karena setiap ingin melaksanakan program harus sistematis sesuai dengan jadwal yang telah ditentukn. Sedangkan koordinasi dalam rangka mendata kader IPM kapas baru dan menjelaskan terkait dengan prosedur pengabdian yang diimplementasikan di kader IPM Kapas Madya Baru, 2) Workshop (pelatihan), tahapan ini mengadakan pelatihan atau workshop dalam rangaka mengkonstruk (membangun) kreativitas kader IPM yang nantinya akan paham bagaimana menghasilkan karya secara produktif melalui perputastakaan mini multisumber. Kemudian yang tidak ketinggalan lagi adalah melatih mohadarah dengan memanfaatkan refrensi buku perpustakaan tersebut, 3) Mini library preparation, tahapan ini tim secara khusus mendesain perpustaan sesuai dengan planning awal, sehingga nantinya menarak perhatian kader IPM untuk memanfaatkan perpustakaan tersebut, 4) Preparation Books, pada tahapan ini tim mengoleksi buku-buku yang dibutuhkan baik yang bersifat relegius, sejarah, novel, pendidikan, dan umum, sehingga bisa menjadi refrensi yang komplet dengan semuanya ada.

\section{b. Implementasi (Implementation)}

Pada proses implementsi program pengabdian kepada masyarakat ini disesuaikan dengan planning awal dengan program yang ditawarkan kepada masyarakat dan melibatkan mitra untuk memudahkan mengimplementasi program perpustakaan mini muliti-sumber yang dilakukan beberapa tahap sebagai berikut: 1) Pembagian Kelompok, tujuannya untuk menjadikan kegiatan lebih efektif dan kolaboratif, sehingga dengan berkelompok anak-anak saling melengkapi satu dengan yang lain. 2) Pelatihan Awal, melakukan pelatihan cara menulis arab maupun umum yang dibimbing langsung oleh tentor, dan cara mengambil refrensi yang sesuai dengan tema besarnya. Dengan dilakukan kelompok seperti memberikan pelatiahan akan lebih maksimal daripada hanya dilakukan secara sendiri. Karena dengan kelompok itulah menjadikan anak-anak saling berkolaborasi dengan yang satu dengan yang lainnya sesuai dengan kelomponya masing-masing, 3) Pelatihan Lanjut, tujuannya pelatiahan lanjut ini sebagai pematangan kepada kader menjadi lebih fokus pada tujuan atau target yang dinginkan. Pada kegitan yang dilakukan oleh kader disesuaikan dengan jadwal yang ditentukan, 4) Pembuatan karya, pada tujuan ini bagaimana anak akan dibiasakan untuk baca tulis, dan menulis menjadi kebutuhan. Sehingga dengan pembudayaan baca tulis dengan melaui perpustakaan mini multi-sumber ini akan menjadikan kader IPM dapat tampil menjadi aset masa depan. Pada 
kegiatan ini dilakukan pengoreksian dari semua hasil karya keder untuk direvisi yang kurang baik dan dikumpulkan jadi satu kesatuan karya.

\section{c. Evaluasi (Evaluation)}

$\begin{array}{ccr}\text { Berbagai } & \text { aktivitas } & \text { yang } \\ \text { dilaksanakan } & \text { dalam } & \text { program }\end{array}$ diharapkan adalah fasilitas perputakaan mini multi-sumber menciptakan budaya baca tulis yang maksimal dengan hasil karya yang akan dipajang dimading IPM dan karya yang bagus akan dikumpulkan menjadi 1 bendel dan dibukukan. Disamping itu, pemberdayan IPM ini akan berkelanjutan melihat potensi Remaja IPM Ranting Kapas Madya Baru yang sangat progresif dengan berbagai kegitan yang memicu pada produktivitas. Kemudian juaga yang menjadi kefokusan pada pengabdian ini adalah bagaimana nanti karya remaja IPM ini dipublikasikan di media online melalui web dan majalah lainnya. Sehingga produktivitas baca tulis dengan menghasilkan karya dengan baik dapat dibuktikan.

Pada substansinya pengadaan perpustakaan multi-sumber upaya menumbuhkan produtivitas baca tulis senantiasa harus terus dievaluasi dalam rangka pembenahan kegiatan yang kurang efektif. Secara khusus diagenda kegiatan yang diimplementasikan mesti ada kekurangan yang harus terus dievaluasi. Karena fungsi evaluasi untuk meninjau ulang selama kegitan berlangsung. Program pengabdian melalui perpustakaan mini multi-sumber ini sangat strategis dalam rangka menumbuhkan kreatifitas remaja diperkampungan. Kemudian yang tidak menjadi ketingga evaluasi yang terus dilakukan agar program ini berjalan dengan mulus sesui dengan target pengabdian.

Oleh karena itu, dari semua itu menjadikan progam sebagai salah satu agenda pengabdian yang produktif dan dapat sedikit banyak dapat meminimalisir dari kenakalan remaja. Karena kenakalan remaja itu terjadi ditengah-tengah kehidupan masyrakat adalah karena mereka tidak ada ruang aktualisasi diri, sehingga mereka akan menjadikan dirinya sesuai dengan kehendaknya. Padahal anak merupakan aset masa depan yang harus didik sedemikian rupa, sehingga menjadi anak-anak yang benar berguna. Pada program ini anak-anak akan difasilitasi dalam mengaktualisasi diri secara masif, sehingga terbentuk karakter yang militan dan tangguh serta produktif.

\section{HASIL PEMBAHASAN}

Kenakalan remaja timbul ditengahtengah masyarakat saat ini tidak lepas dari sebab awal yang memicu menjadikan mereka tidak sesuai dengan norma-norma yang ada. Kenakalan remaja merupakan kecenderungan remaja untuk mengaktualisasi diri dengan melanggar aturan yang dapat kerugian dan kerusakan baik terhadap dirinya sendiri lebih-lebih pada orang lain. Sedangkan hal itu dilakukan oleh remaja rentang usia kurang lebih 13-17 tahun. Remaja yang berperilaku nakal atau anarkis lainnya diindikasikan memiliki tingkat pemahaman dan kedalaman agama yang relatif rendah dan kontrol diri juga yang rendah. Karena salah satu faktor yang mempengaruhi kenakalan remaja adalah kontrol diri. Remaja yang gagal dalam mengembangkan kontrol diri yang cukup dalam hal tingkah laku berarti gagal dalam mempelajari perilaku yang dapat diterima dan perilaku yang tidak dapat diterima oleh masyarakat (Aviyah \& Farid, 2014).

Sejalan dengan itu program penagabdian ini menjadikan para remaja sesuai dengan yang diharapkan dalam rangka pemberdayaan. Kanakala remaja secara tidak lingsung dipengaruhi oleh lingkungan sekitar secara empiris, seperti yang dikatakan oleh John Lock (1632$1704 \mathrm{M})$ bahwasanya manusia dilahirkan dalam keaadaan tidak membawa apa-apa (Tabularasa), namun yang mempengaruhi perkembangan dirinya adalah lingkungan sekitarnya. Sehingga implementasi program pengabdian melalui perpustakaan mini multi-sumber tujuan 
utmanya adalah dalam rangka meminimalisir dari kenakalan remaja yang terjadi ditengah-tengah masyarakat yang meresahkan. Karena dalam menyelesaikan masalah remaja tidak dilakukan secara instan, namun harus dilakukan secara berkelanjutan. Dari situlah sejalan dengan berjalannya waktu proses akan menentukan mencetak remaja yang tanggu dan cinta dalam kemaslahatan.

Untuk masa remaja gaya pengasuhan yang baik dan relevan berdampak signifikan pada sikap percaya diri, keterampilan sosial yang baik, moral yang kuat (sikap sosial yang konsisten) dan prestasi akademik yang tinggi (Sriyanto dkk, 2014). Pengasuhan model pelatihan-pelatihan (workshop) berkelanjutan beberdampak pada potensi remaja IPM terhadap perkembangan kognitif yang humanis. Sehingga program pengasuhan dan pelatihan seperti ini pada usia remaja yang dibentuk melalui IPM biasanya adalah cenderung beprestasi secara produktif. Sehingga pengasuhan yang dilakukan sejak dini melalui ikatan pelajar Muhammadiyah (IPM) melalu desain program yang diimplementasikan berdampak pada perkembangan kognitifnya.

Impelementasi pengabdaian yang diprogram ini sebagai wujud aktualisasi ilmu pengetahuan dalam rangka meminimalisir dari kenakalan remaja yang marak terjadi saat ini. pola pengasuhan yang baik terhadap anak berpengaruh positif terhadap perilaku tidak baik harus dimasifkan. Hal ini yang terjadi sebaliknya dengan melalui media informasi yang semakin canggih kadang menjadi konsumtif setiap harinya, sehingga berpengaruh negatif terhadap perilaku menyimpang yang tidak sesuai dengan aturan yang ada (Nindya \& Margaretha 2012). Seperti yang dikatakan oleh Ki Hajar dewantara ada three pusat pendidikan yang memicu baik tidaknya periku anak, diantaranya yaitu, lingkungan keluarga, masyarakat dan sekolah. Dari tiga lingkungan itu harus benar-benar kondusif dan saling koopretif satu sama lain.

Selain itu, memaksimalkan pengendalian remaja dengan melalui budaya leterasi dengan perpustakaan mini yang dapat menjembatani permasalahan yang berkaitan dengan kenakalan remaja yang memang saat ini sudah meraja lela dimana-mana. Karena lingkungan kapas madya baru memang relatif pemuda atau remajanya sangat banyak, yang terlihat cenderung nakal-nakal (Aviyah, E \& Farid, M. 2014). Namun karena memang remaja sensetif terhadap lingkunagan sekitar tentunya program pengambdian yang diiplementasikan di ranting kapas maya baru bertempat di Masjid Alfurqan, merupakan tempat strateges memperdayakan para remaja untuk meningkatkan produktivitsya sebagai pembaca dan penulis melalui perpustakaan mini. Sehingga dengan model kegiatannya setidaknya para remaja dilingkungan kapas baru dapat diminimalisir sedikit demi sedikit. Diberbagai itu pula anak diberikan pemahaman yang membuat dirinya percaya atas kemampuan dirinya sendiri, sehingga dapat menjadikan mereka produktif (Hariz, S. A. 2014)

Pelatiahan atau workshop yang diberikan kepada remaja yang dibentuk dalam ikatan pelajar muhammadiyah (IPM) dapat memberikan kontribusi positif terhadap kenakalan remaja yang tidak kunjung usai ditengah-tenagah masyarakat saat ini dan yang akan datang. IPM adalah sebagai garakan amar makruf nahi mungkar yang sesuai dengan tujuan muhammadiyah menjadikan kadernya slalu progresif untuk meningkat produktivitasnya. Maka dengan pelatihan yang diprogramkan oleh tem pengabdian dalam rangka menjadikan kader IPM yang senantiasa berwawasan tingga dengan media perpustakaan mini muti-sumber dengan varian kegitan yang memicu produktifitas tinggi para kader IPM.

Pada dasarnya remaja sesunggunya memiliki spirit yang luar bisa untuk melakukan perubahan. Energi positif itu terpancar ketika mereka melihat suatu 
kejanggalan pada bumi pertiwi. Pola pikir dan daya analisis yang tinggi terhadap masalah bangsa membuat mereka merasa terpanggil untuk melakukan percepatan perbaikan tanah air menuju ke arah yang lebih baik. Persaingan global yang semakin panas ditambah pesatnya perkembangan dunia teknologi membuat ekonomi diindonesia semakin jauh tertinggal. Sehingga faktor lain yang juga ikut mempengaruhiperilaku kenakalan pada remaja adalah konsep diri yang merupakan pandangan atau keyakinan diri terhadap keseluruhan diri, baik yang menyangkut kelebihan maupun kekurangan dirinya, sehingga mempunyai pengaruh yang besar terhadap keseluruhan perilaku yang ditampilkan oleh remaja (Muniriyanto \& Suharnan. 2014).

Tanggapan positif dari lingkungan baik terhadap keadaan remaja IPM akan menimbulkan rasa puas dan menerima keadaan dirinya tidak lepas dari desain program pengabdian yang dilakukan secara tim, secara keseluruhan menjadikan kegitan tersekenggara dengan maksimal. Oleh karena itu, terbentuknya IPM kapas madya baru merupakan usaha sadar yang dilakukan oleh ranting Muhammdiyah kapas baru dengan maksimal, yang akhirnya akan menjadikan memilki kompotensi yang menjadi bekalnya. Karena dengan kompotensi yang dimiliki akan menjadi kepribadian kader IPM yang produktif dan menyesuaikan dengan norma-norma yang ada. Kemampuan remaja dengan difasilitasi akan menjadikan tujuan hidupnya terarah.

\section{SIMPULAN}

Dari implementasi pengabdian yang telah dilakukan menunjukkan bahwa dengan pengadaan perpustakaan mini multi-sumber dengan berbagai desain pelatiahan yang maksimal, dapat disimpukan bahwa a) Pelaksanaan program kegiatan ini mampu menciptakan budaya baca tulis secara produktif melalui pengadaan perpustakaan multi-sumber, $b$ ) Mampu menciptakan tulisan yang baik dan benar melalui pelatihan workshop atau pelatihan-pelatiahan yang sudah diprogram, c) Memberikan aternatif yang sulutif melalui kegiatan IPM terkait dengan kenalalan remaja yang saat ini sultit terbendung menjadi lebih produktif menjauhkan dari kenakalanny, d) Menjadikan nilai tambah pengetahuan melaui perpustakaan mini mult-sumber dalam meningkan produktivitas baca-tulis remaja IPM di Kapas Madya Baru Masjid Al-Furqan III/3 Surabaya.

\section{DAFTAR PUSTAKA}

Aviyah, E \& Farid, M. (2014). Religiusitas, Kontrol Diri Dan Kenakalan Remaja. Persona, Jurnal Psikologi Indonesia. Vol. 3, No. 02, hal $126-129$

Hariz, S. A. 2014. Hubungan Antara Persepsi Keharmonisan Keluarga Dan Konformitas Teman Sebaya Dengan Kenakalan Remaja. E-Jurnal Dinas Pendidikan Kota Surabaya; Volume 2. ISSN : 2337-3253

Muniriyanto \& Suharnan. 2014. Keharmonisan Keluarga, Konsep Diri Dan Kenakalan Remaja. Persona, Jurnal Psikologi Indonesia, Vol. 3, No. 02, hal $156-164$.

Nindya P . N \& Margaretha R. (2012). Hubungan

antaraKekerasanEmosional pada Anak terhadap Kecenderungan Kenakalan Remaja. Jurnal Psikologi Klinis dan Kesehatan Mental Vol.1.No.02.

Sriyanto dkk. (2014). Perilaku Asertif dan Kecenderungan Kenakalan Remaja Berdasarkan Pola Asuh dan Peran Media Massa. JURNAL PSIKOLOGI,VOLUME 41, NO. 1, $74-88$ 